This item was submitted to Loughborough's Research Repository by the author.

Items in Figshare are protected by copyright, with all rights reserved, unless otherwise indicated.

\title{
Securitisation and banking risks: what do we know so far?
}

PLEASE CITE THE PUBLISHED VERSION

http://dx.doi.org/10.1108/RBF-07-2014-0039

\section{PUBLISHER}

(c) Emerald

\section{VERSION}

AM (Accepted Manuscript)

\section{PUBLISHER STATEMENT}

This work is made available according to the conditions of the Creative Commons Attribution-NonCommercialNoDerivatives 4.0 International (CC BY-NC-ND 4.0) licence. Full details of this licence are available at: https://creativecommons.org/licenses/by-nc-nd/4.0/

\section{LICENCE}

CC BY-NC-ND 4.0

\section{REPOSITORY RECORD}

Kara, Alper, Aydin Ozkan, and Yener Altunbas. 2019. "Securitisation and Banking Risks: What Do We Know so Far?". figshare. https://hdl.handle.net/2134/21693. 


\title{
Securitisation and banking risk: What do we know so far?
}

\author{
Yener Altunbaș \\ Bangor Business School, UK \\ Alper Kara ${ }^{1}$ \\ Hull University Business School, UK \\ Aydın Özkan \\ Bradford University School of Management, UK
}

\begin{abstract}
Purpose - Bank securitisation is deemed to have been a major contributing factor to the 2007/08 financial crises via fuelling credit growth accompanied by lower banks' credit standards. Yet, prior to the crisis a common view was that securitisation activity makes the financial system more stable as risk was more easily diversified, managed and allocated economy-wide. In this survey paper we review the extant literature to explore the so far generated knowledge on the impact of securitisation on banking risks. In particular, we examine the theoretical arguments and empirical studies on securitisation and banking risks before and after the global financial crisis of 2007/08. We identify the limitations of empirical studies and assess the comparability of findings.

Findings - Theoretical literature univocally accentuate the undesirable consequences of securitisation, which may promote retention of riskier loans, undermine banks' screening and monitoring incentives and enhance banks' risk appetite. However, empirical evidence does not uniformly support the theoretical conclusions. If banks are securitisation active they lend more to risky borrowers, have less diversified portfolios and hold less capital, retain riskier loans and are aggressive in loan pricing. Others argue that securitisation reduces banks insolvency risk, increases profitability, provides liquidity and leads to greater supply of loans. Mortgage securitisation is an area where there is consistent evidence of bank risk taking via securitisation.
\end{abstract}

Design/methodology/approach - Review and discussion of the literature.

Originality/value - The paper identifies open issues for future research.

Keywords - securitisation, banking risks, financial crisis

${ }^{1}$ Corresponding author: a.kara@hull.ac.uk 


\section{Introduction}

Bank asset-backed securitisation (ABS) is the process whereby various types of loans are pooled together into tradable securities which are then sold on to a range of investors. Buyers of ABS receive regular payments reflecting the interest and principal payments made by the borrowers of the underlying loans. The process of securitisation has significantly changed banks role of acting as intermediaries between borrowers and depositors. Traditional bank lending is about extending loans, holding them until the maturity and monitoring of borrowers' performance during the process. In this "originate to hold" model, banks reduce idiosyncratic risks mainly through portfolio diversification and perform the role of delegated monitors for less informed investors (Diamond, 1984; Ramakrishnan and Thakor, 1984; Bhattacharya and Chiesa, 1995; and Holmstrom and Tirole, 1997). Within this framework, securitisation allows banks to turn illiquid loans into marketable securities to be sold to others. It enables banks to off-load part of credit exposure to outside investors and raise new funds to increase lending further - operating in a so called "originate to distribute" model.

The transformation of banks from traditional lenders to originators and/or distributors of loans have had implications on bank behaviour. The sceptical view was that, by creating distance between the loan's originator and the bearer of the loan's default risk, securitisation could reduce banks screening and monitoring incentives, particularly for loans sold on to other investors and no longer on the banks' balance sheet (Petersen and Rajan 2002). It could also lead to holding riskier loans and package and sell the better quality ones, making the bank loan portfolios more vulnerable. This is due to the fact that banks need to signal quality of the securitised assets to the market by retaining riskier loans. Furthermore, securitisation could enhance the risk appetite of banks as they could transfer the risk with the ability to sell the loans to others. Hence, leading to lax lending standards by banks, securitisation could threaten financial stability and make the financial system more fragile by building up imbalances in credit markets.

In contrast, securitisation provided a mechanism for the financial system where concentrated credit and portfolio risks of the banking sector can be dispersed to the rest of the capital markets through buyers of securitised assets. The distribution of the risk economy-wide through 
securitisation was expected to make the financial system more stable and resilient. Securitisation was expected to avail banks to hold less risk and manage credit risk more effectively. Even if the total risk remained within the banking sector, securitisation was expected to allow banks to hold less risk simply due to diversification and more tradability (Duffie, 2008). In fact, prior to the 2007/08 crisis leading regulatory authorities (such as Fed's Alan Greenspan, 2005) praised securitisation emphasizing that such credit risk transfer instruments enabled banks to reduce the credit risk by passing it on to other financial and non-financial institutions and investors.

In general, it is argued that securitisation provides benefits to greater part of the participants of the financial system. For banks, and other type of financial institutions, transforming illiquid assets to tradable capital market instruments securitisation can provide an alternative source of financing. It reduces banks' dependency on deposits and provides diversification of financing sources which may lead to lower cost of financing. Improved liquidity improves the solvency of banks and the higher asset turnover would increase the overall profitability. This efficiency created by securitisation in banks balance sheet in turn leads to increasing the availability of financing at a lower cost for companies and other borrowers of credit in the primary markets. For institutional investors, securitised assets are an alternative to other capital market products, such as government and corporate bonds, and offers diversification opportunities and higher yields for portfolios.

The global financial crisis of 2007/08 has drawn much attention to securitisation and its role during and on the build up to the crisis. During the crisis securitisation markets collapsed catastrophically after mortgage related instruments experienced severe credit quality deterioration. Subsequent spill over to other types of ABS led to large losses by investors of ABS. Prior to the crisis some banks' business model of funding their operations through securitisation is blamed to fuel credit growth and leverage in the economy. It is also argued that securitisation impacted as an incentive mechanism for banks' un-measured risk taking behaviour.

Recent developments in financial markets signal that banks themselves may have already acknowledged their oversight of taking un-measured risk through securitisation. At the time of writing, in the US, JP Morgan and Bank of America agreed to pay USD 4.5 and 9.1 billion, 
respectively, to settle court cases with institutional investors. They claim that mortgage backed securitised assets sold to them prior to the financial crisis defaulted catastrophically leading to large losses. Similarly, the US Federal Housing Finance Agency reached settlements of around USD 16.5 billion with 18 financial institutions alleged to be involved securities law violations and fraud in the sale of mortgage backed securities to Fannie Mae and Freddie $\mathrm{Mac}^{2}$. On a separate case, Citigroup and JP Morgan Chase agreed to pay around total of USD 15 billion to the US Department of Justice over allegations it misled investors about mortgage-backed securities in the time leading up to the 2007/08.

In this survey paper we review the extant literature to explore the so far generated knowledge on the impact of securitisation on banking risks. In particular, we examine the theoretical arguments and empirical studies on securitisation and banking risks prior to the financial crisis and the post financial crisis period. We identify the limitations of empirical studies and assess the comparability of findings.

We find that theoretical literature univocally accentuate the undesirable consequences of securitisation $^{3}$, which may promote retention of riskier loans by banks, undermine on banks' screening and monitoring incentives and enhance banks' risk appetite. Overall securitisation may not lead to credit risk diversification throughout the economy. However, we find that empirical evidence on the issue does not uniformly support the theoretical conclusions. There is evidence that if banks are securitisation active they lend more to risky borrowers, have less diversified portfolios and hold less capital, retain riskier loans and are aggressive in loan pricing ${ }^{4}$. Others show that securitisation reduces banks insolvency risk, increases profitability, provides liquidity and leads to greater supply of loans ${ }^{5}$. We also find that mortgage lending is an area where there

\footnotetext{
${ }^{2}$ These include CitiGroup, UBS Americas, JP Morgan Chase, Deutsche Bank, Morgan Stanley, Societe Generale, Credit Suisse, Bank of America, Merrill Lynch, Barclays Bank, RBS Securities and Wells Fargo Bank among others.

3 Theoretical studies include: Plantin (2004), DeMarzo (2005), Greenbaum and Thankor (1987), Gorton and Pennacchi (1995), Krahnen and Wilde (2006), Chiesa (2008), Parlour and Plantin (2008), Wagner (2007), Insterjord (2005), Shin (2009) and Brunnermeier and Sannikov (2010)

${ }^{4}$ These studies include: Cebenoyan and Strahan (2004), Haensel and Krahnen (2007), Franke and Krahnen (2005), Casu et al., (2013), Calem and LaCour-Litle (2003), Martin-Oliver and Saurina (2007), Kara et al., (2011), Bannier and Hansel (2006), Michalak and Uhde (2009) and Affinito and Tagliaferri (2010).

5 These studies include: Jiangli and Pritsker (2008), Cebenoyan and Strahan (2004), Loutskina and Strahan (2009), Loutskina (2011), Altunbas et al., (2009) and Goderis et al., (2007).
} 
is consistent evidence of bank risk taking via securitisation ${ }^{6}$. Banks active in mortgage securitisation originated poor-quality mortgages, had lower denial rates, had higher loan default rates and lost their screening and monitoring incentives.

The remainder of the paper is organised as follows: Section 2 provides a technical background for the securitisation process and its counterparties. Section 3 examines the literature generated prior to the financial crisis while Section 4 looks at the post crisis period. Section 5 concludes with suggestions for further research and regulatory implications.

\section{Background and Mechanics of Securitisation}

Securitisation can simply be defined as the process whereby cash-generating financial assets, such as mortgages ${ }^{7}$, corporate loans, and auto loans are pooled together into tradable securities. Cash flows or economic values of these assets are then redirected to support payments on the created securities. These securities are then sold on to a range of investors including other banks, insurance companies and funds. The investors receive regular payments reflecting the interest and principal payments made by the underlying borrowers of the assets backing the securities. The intended goal and effect of a securitisation transaction is to isolate the loans (or other assets) that support payments on the ABS [European Securitisation Forum (ESF), 2006]. This ensures that payments on the ABS are derived exclusively from the performance of a segregated pool of loans rather than from the originator bank that holds the loans. The fundamentals of securitisation are relatively basic and common to nearly all types of transactions. As a result, the process of securitisation and its structure is similar even in different countries, under different legal and regulatory structures (ESF, 2006).

Figure 1 displays the basic securitisation process and its participants. The assets that underlie a securitisation transaction are created when a bank extends loan to a borrower (also obligor). To create the ABS the originator bank conveys the loans to a bankruptcy remote special purpose

${ }^{6}$ Studies providing evidence to this argument are Keys et al., (2010), Purnanandam (2010), Dell'Ariccia et al., (2010) and Mian and Sufi (2009).

${ }^{7}$ Often called commercial and residential mortgage backed securities. 
vehicle $(\mathrm{SPV})^{8}$ which then issue (as the issuer) the debt securities in the capital markets to be sold to other investors. The proceeds from the issuance of the securities are then used by the SPV to pay the price of the loans to the originator bank. A true sale is necessary in order to remove the loans from bankruptcy or insolvency of the originator bank.

Often the ABS may be supported by credit support to boost the risk profile and these enhancers can be supplied by a third party for a fee or provided by the originator bank [Association for Financial Markets in Europe (AFME), 2014]. A common form of credit enhancement is tranching of the risk of loss (due to default of underlying borrowers). Tranching takes the form of a capital structure for the SPV, with some senior-rated tranches sold to investors in the capital markets, a junior security which is typically privately placed $^{9}$, and various forms of equity-like claims (Gorton and Souleses, 2004). These tranches differ in characteristics - such as payment, coupon, maturity etc - and levels of risk. The underwriter is heavily involved with designing of the tranches. Credit enhancement also takes a variety of other forms including overcollateralization, securities backed by a letter of credit, or a surety bond, or a tranche may be guaranteed by a monoline insurance company. In most cases, independent credit ratings from leading rating agencies are obtained at issuance for investor guidance. The issuance of securities is generally undertaken by an underwriter that serves as an intermediary between the SPV and investors. During the lifetime of the securities originator bank often acts as the servicer for the collection of principal and interest from the borrowers whose loans are securitised and reports back to the investors on the performance of the underlying assets.

\footnotetext{
${ }^{8} \mathrm{An} \mathrm{SPV} \mathrm{(also} \mathrm{called} \mathrm{a} \mathrm{special} \mathrm{purpose} \mathrm{entity)} \mathrm{is} \mathrm{a} \mathrm{legal} \mathrm{entity} \mathrm{created} \mathrm{by} \mathrm{an} \mathrm{originator} \mathrm{(a} \mathrm{bank} \mathrm{or} \mathrm{a} \mathrm{non-financial}$ firm) by transferring assets to the SPV, to carry out some specific purpose or circumscribed activity, or a series of such transactions. SPVs have no purpose other than the transaction(s) for which they were created, and they can make no substantive decisions; the rules governing them are set down in advance and outline their activities. Indeed, an SPV has no physical location. Typically, off-balance sheet SPVs have the following characteristics: they are thinly capitalized; they have no independent management or employees; their administrative functions are performed by a trustee who follows; prespecified rules with regard to the receipt and distribution of cash; there are no other decisions; assets held by the SPV are serviced via a servicing arrangement; and they are structured so that, as a practical matter, they cannot become bankrupt (Gorton and Souleses, 2004).

${ }^{9}$ The ABS issue can be placed publicly as well as privately.
} 


\section{Figure 1: A basic securitisation structure}

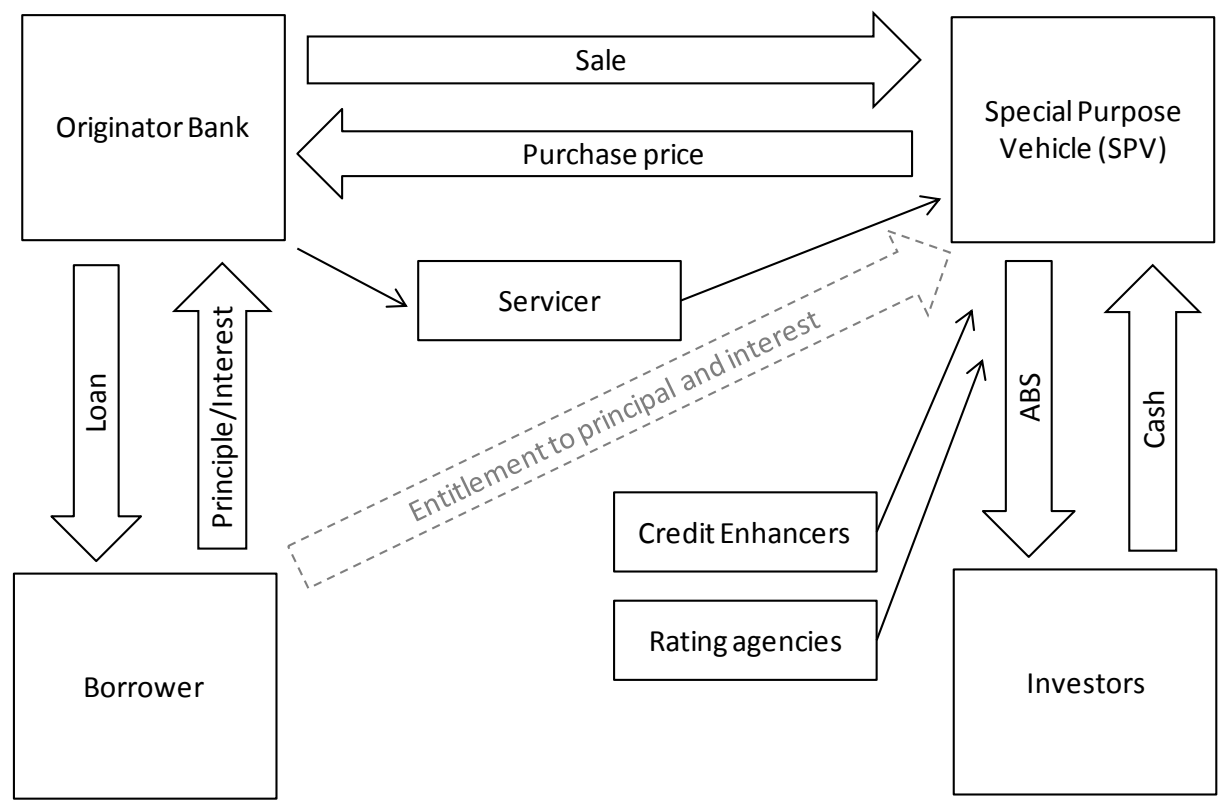

Source: Authors own graph

In order to signal the quality of the securitised assets and align its interests with those of investors, the originator (i.e. the bank) of the assets may retain part of the equity tranche on its balance sheet. The objective is to bridge asymmetries of information between originators and the final investor via the retention of the lowest ranked (e.g. equity) tranche. This retention generally seen in practice is the result of a signalling equilibrium where the securitising bank, in an attempt to signal the value of assets, retains some of the securitised assets (DeMarzo, 2005; Greenbaum and Thankor, 1987; and Instefjord, 2005).

The US and Europe are the main markets for the securitisation activity. Although securitisation originated in the US and has been used by banks since the late 1960s, it became popular as a financial instrument in the early 2000s and grew swiftly both in Europe and the US. However, the volume of the securitisation activity in the US has been significantly larger than Europe (see Figure 2). 
Figure 2: Securitisation volume in Europe and the United States (billions Euro)

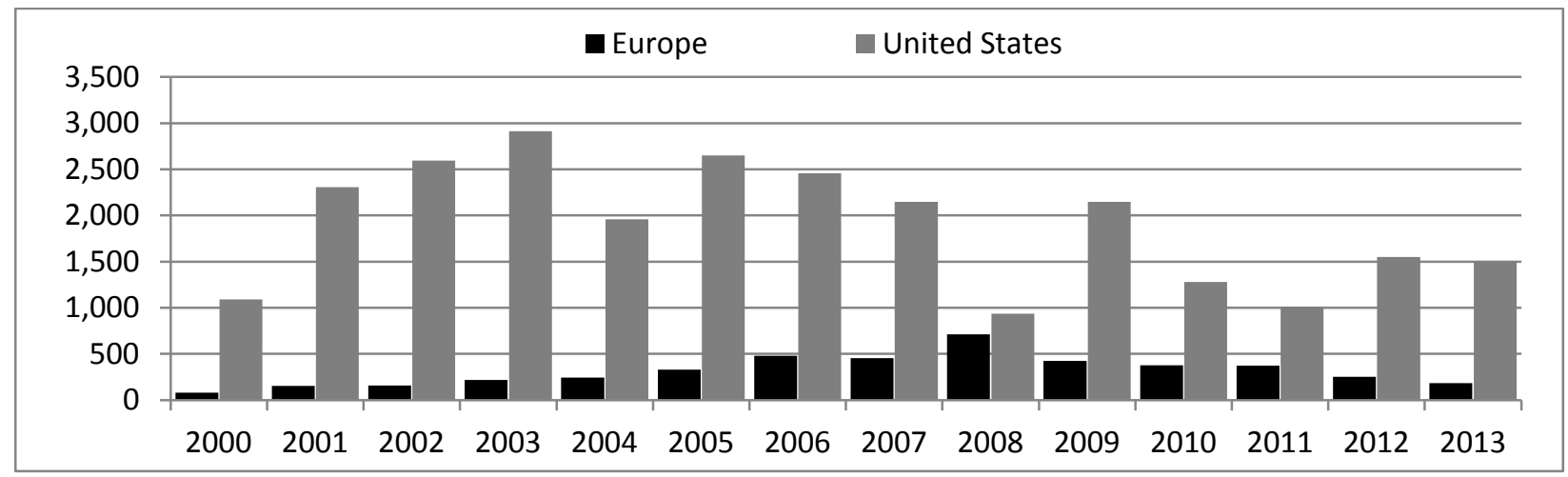

Source: Authors' calculations from datasets provided in AFME (2013), p. 3

Another difference between these two regions is the structure of the market. In the Unites States the development of the securitisation market is driven by government sponsored agencies (such as Fannie Mae and Freddie Mac). These agencies enhanced mortgage loan liquidity by issuing and guaranteeing asset backed securities. Securitisation, supported by the government agencies, has played a key role in the growth of residential mortgage lending in the US. Figure 3 displays the distribution of securitisation products that were issued in 2007 in Europe and the US. Agency related Mortgage Backed Securities (Agency MBS) that constitute around 45 percent of the market in the US, however, does not exist in Europe.

\section{Figure 3: Distribution of securitisation types Europe and the United States}
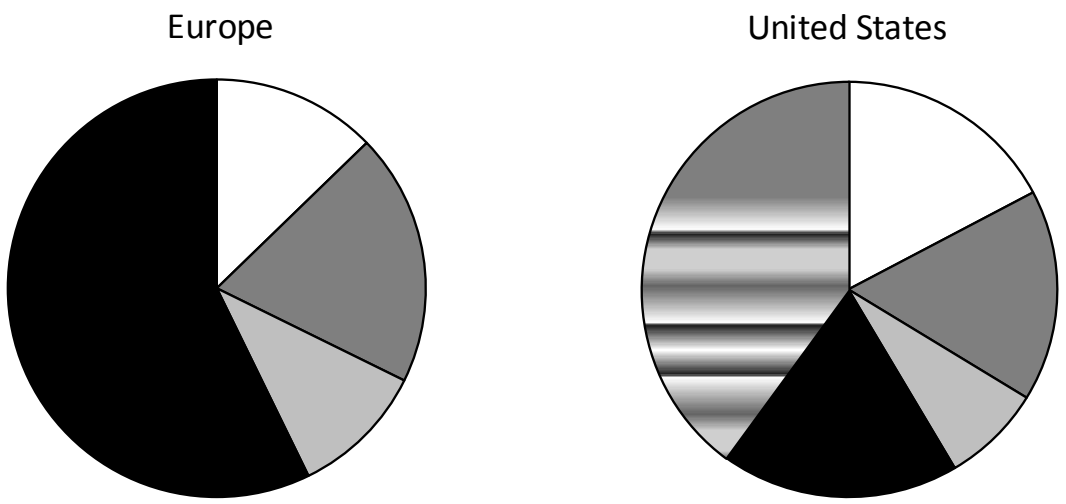

$\square \mathrm{ABS}$

$\square \mathrm{CDO}$

$\square \mathrm{CMBS}$

- RMBS

$\square$ Agency MBS

Source: Authors' calculations from datasets provided in $\operatorname{AFME~(2007,~2013),~p.~} 3$ 


\section{Literature review: prior to the $2007 / 2008$ financial crisis}

There are two opposing views as to the costs and benefits of securitisation on banking risks and the financial system in general. In this section, we present research conducted prior to the 2007/08 crisis beginning with the negative consequences of securitisation.

\subsection{Destabilising the financial system}

Prior to the financial crisis, the academic literature, especially theoretical papers, raised concerns regarding the possible negative impact of securitisation on bank lending standards and the stability of the financial system. Some argued that securitisation does not necessarily lead to credit risk diversification, but could promote the retention of risky loans and undermine banks' screening and monitoring incentives (Greenbaum and Thankor, 1987; Gorton and Pennacchi, 1995; Krahnen and Wilde, 2006; Parlour and Guillaume, 2008; and Chiesa, 2008). Others noted that by making illiquid loans liquid, securitisation could enhance the risk appetite of banks (Calem and LaCour, 2003; Haensel and Krahnen, 2007; and Wagner, 2007). The link between lax lending standards and fragility of the financial system is an evident one. If securitisation activity leads to excessively lax lending standards by banks it could have an impact on the overall financial stability by building up imbalances on credit markets that can make the overall system more fragile.

One risk factor with securitisation is the possibility of banks securitising the better loans and keeping the riskier ones in their portfolios, overall making banks' portfolios weaker and vulnerable to economic downturn. Keeping the riskier loans (or tranches of ABS) may be a necessity. Plantin (2004) and DeMarzo (2005) show that the retention of the first loss piece aligns the incentives of the issuing bank with the interests of the buyers of senior tranches. In a seminal paper Greenbaum and Thankor (1987) show that with asymmetric information (but without government intervention) better quality assets will be securitised and poorer quality assets will be retained in banks balance sheet - funded with deposits. Gorton and Pennacchi (1995) analyzed a model of bank loan sales and show that loan sales is only possible if the selling bank retained a fraction of the riskier loans (or give implicit guarantees) to signal quality. Their analysis provides empirical support for the prediction of their theoretical model that a bank 
will retain a greater proportion of more risky loans in securitisation. Similar to loan sales in securitisation banks often retain the first loss piece - the riskiest trench of the ABS. Providing evidence for this argument using simulations, Krahnen and Wilde (2006) find an increase in the systemic risk of banks, after securitisation, due to the retention of the first loss piece. Ambrose et al. (2005), looking at MBS in the $\mathrm{US}^{10}$, find evidence that loans securitised by banks reduce yield spreads by about 23 basis points relative to the loans kept on the banks balance sheet. They also show that securitised loans have experienced lower ex-post defaults than those retained in portfolio.

It is argued that regulation may have played a role for banks to keep the riskier loans. Asset securitisation allows the intermediary to leverage its capital more efficiently and increase the returns associated with its private information (DeMarzo, 2005). It has often been used by banks to lower their regulatory needs for costly equity capital charges related to loans on the balance sheet, thereby reducing the overall cost of financing (Watson and Carter, 2006). The regulatory approach prior to the 2007/08 financial crisis (Basel I and later Basel II) promoted the growing use of securitisation that enable institutions to reduce regulatory capital requirements with little or no corresponding reduction in overall economic risk. However, banks may have an incentive to securitise less risky loans thereby lowering their capital positions (Calem and LaCour-Litle, 2003). This behaviour derives from the existence of high capital standards to exploit the benefits of securitising assets to undertake regulatory capital arbitrage. Through securitisation banks can potentially increase capital adequacy ratios without decreasing their loan portfolios' risk exposure. Bannier and Hansel (2006) support this argument with the European data and find that regulatory capital arbitrage (under Basel I) had been driving the market ${ }^{11}$. They highlight that loan securitisation is mostly used by as a funding tool for banks with high risk and low liquidity $^{12}$. In this direction also, Krahnen and Wilde (2006) question whether securitisation affects the cyclicality of bank equity values, which reflects a major component of systemic risks in the banking market, caused by correlated defaults of loans in the banks' loan books. Their

\footnotetext{
10 The data used for this research consist of event histories on 14,285 conventional fixed rate mortgages originated between January 1995 and December 1997 by a US bank.

11 The study includes 316 large European banks for the period between 1997 to 2004 .

12 However, Minton et al. (2004) and Calomiris and Mason (2003) argues otherwise, suggesting that securitisation is a contracting innovation aimed at lowering financial distress costs rather than an outgrowth of poorly structured regulations.
} 
theoretical framework shows that (under plausible assumptions concerning bank reinvestment behaviour and capital structure choice) the banks' systematic risk tends to rise, leading to an increase in the systemic risk of the entire banking sector.

A second risk factor is the possible deterioration in banks' monitoring incentives. This is particularly relevant to the monitoring of borrowers whose liabilities form the basis of the ABS. Chiesa (2008) shows that in cases where banks provide credit enhancement guarantees for securitisation, the extent of credit enhancement needs to be precisely delimited and must be within a defined interval. Outside that interval, monitoring incentives are undermined. Parlour and Plantin (2008) argue that banks' ability to benefit from inside trading, through securitisation or loan sales, reduces their incentives to monitor ex ante.

A third risk factor is the potential of securitisation activity making further acquisition of risk more attractive for banks. Wagner (2007), in a theoretical setting, show that the benefits of increased liquidity through securitisation, stemming from higher risk transfer in the secondary markets, are counteracted through more risk taking in primary markets. In total, stability is even reduced because the improved liquidation possibilities in a crisis reduce banks' incentives to avoid a crisis. Banks therefore take on an amount of new risks that leads to a higher probability of default. Furthermore, Insterjord (2005) highlights that when the bank has access to a richer set of tools to manage risk than before it behaves more aggressively in acquiring new risks.

Empirical evidence is also supportive of this view. For example, Cebenoyan and Strahan (2004), using data from loan sales between 1987 and 1993, find that US commercial banks active in loan sales lend more of their assets to risky borrowers. In a similar vein, Haensel and Krahnen (2007) find that activity in the European collateralised debt obligation (CDO) market enhances the banks' risk appetite and tends to raise the systematic risk (equity beta) of the issuing bank ${ }^{13}$. Franke and Krahnen (2005) report similar findings in an analysis of European CDO securitisations issued between 1999 and 2002. Using a sample of cash and synthetic securitisation transactions issued by 55 stock listed bank holdings over the period from 1997 to 2007, Michalak and Uhde (2009) provide empirical evidence that credit risk securitisation has a

\footnotetext{
13 This study includes 178 ABS-transactions in 2004 from 49 different European banks.
} 
negative impact on banks' financial soundness in Europe. Finally, Casu et al. (2013), using predominantly pre-crisis U.S. commercial bank data between 2001 and 2008, report that securitising banks tend to hold larger and less diversified loan portfolios, have less liquidity, and hold less capital, which are closely associated with the definition of a "risky" bank. Other studies, mostly focused on European data, also provide evidence for the negative impact of securitisation on bank risk taking and financial stability. Using data on Spanish banks between 1999 and 2006, Martin-Oliver and Saurina (2007) show that banks tend to use forms of securitisation that do not shift credit-risk and do not provide regulatory capital relief. For Italy Affinito and Tagliaferri (2010) find that banks are more likely to securitise higher volume of loans when they are less capitalised, have lower profitable and less liquidity ${ }^{14}$.

\subsection{Enhancing the resilience of the financial system}

An opposing view of the one presented above championed the positive role played by securitisation. In a theoretical analysis, Jiangli et al., (2007) suggest that securitisation is associated with increased bank leverage, and profitability, and potentially with lower bank tail risk. Testing these predictions using a dataset from the US mortgage data, Jiangli and Pritsker (2008) find that banks use mortgage securitisation to reduce insolvency risk and increase leverage and profitability. A number of empirical studies reported positive effects of securitisation on banks' risk levels claiming that securitisation mechanism disperses credit risk among many investors thereby enhancing the resilience of the financial system and improve financial stability. Banks that are more active in the securitisation market were found to have lower solvency risk and higher profitability. For instance, Cebenoyan and Strahan (2004) show that, through loan sales, US commercial banks improve their ability to manage credit risk and increase their profitability. Holding size, leverage and lending activities constant, they also report that banks that are active in the loan sales market have lower risk than other banks.

Securitisation also has a direct positive impact on the quantity of loans supplied by banks. Cebenoyan and Strahan (2004) argue that loan sales lead to greater credit availability without necessarily reducing risk in the banking system. Loutskina and Strahan (2009), examining the US MBS market prior to the 2007/08 financial crisis, conclude that securitisation provides

\footnotetext{
${ }^{14}$ Dataset covers a period between 2000 and 2006.
} 
balance sheet liquidity to banks and increases their willingness to supply credit ${ }^{15}$. They argue that overall securitisation fosters financial integration and investor diversification, which facilitates risk sharing and risk management. As an extended work, Loutskina (2011), with a sample of US banks reporting between 1976 and 2007, show that securitisation reduces banks' holdings of liquid securities and increases their lending ability and makes bank lending less sensitive to cost of funds shocks. Looking at the European data, Altunbas et al. (2009) also arrive at similar conclusions that European banks that are active in the securitisation market also seem to supply more loans for the period between 1999 and 2005. Goderis et al. (2007) confirm these findings with an international dataset using data from 65 securitisation active banks between 1995 and 2004

\section{Literature review: post 2007/2008 financial crisis}

Bank securitisation suddenly became a hot topic in academic circles after the 2007/2008 financial crisis. In particular, it has been under scrutiny for fuelling credit growth by banks, lowering banks' credit standards and creating a false sense of diversification of risks - in other words, being one of the main causes of the financial crisis (Kara et al. 2011). Most of these arguments rely on the line of reasoning presented above as the negative consequences of securitisation on bank behaviour. Shin (2009) provides a theoretical framework showing how securitisation by itself may not enhance financial stability if the imperative to expand bank balance sheets drives down lending standards. He explains that, prior to the financial crisis, as balance sheets expanded via securitisation banks look for new borrowers and when all prime borrowers had loans they had to lower their lending standards in order to lend to subprime borrowers. Moreover, these bad loans were not all passed on to final investors and sat inside the financial system. This is because although SPVs are separate legal entities from the originator banks, banks had exposures to them via various forms of retained interest (as explained above in Section 2). Brunnermeier and Sannikov (2010) argue that while risk sharing within the financial sector, through securitisation and other derivatives contracts, reduces many inefficiencies, it can lead to higher leverage and amplify bank risks.

${ }_{15}$ The data used in this study covers sample of mortgage applications and originations that have been collected by the Federal Reserve under provisions of the Home Mortgage Disclosure Act (HMDA) and covers loan applications from 1992 to 2004. 
It is worth to note at this point that empirical studies produced after the 2007/08 on securitisation examine the data generated prior to the 2007/08 financial crisis. However, typically they focus on the build up period between 2005 and 2007. Studies, particularly focusing on US mortgage data, provide evidence of lax lending standard practices by US banks. For example, Keys et al. (2011) show that a doubling of securitisation volume by the bank is on average associated with about a $10 \%-25 \%$ increase in defaults in loan portfolios. They find that existing securitisation practices did adversely affect the screening incentives of subprime lenders. Furthermore, existing securitisation practices did not ensure that a decline in screening standards would be counteracted by requiring originators to hold more of the loans' default risk. Arriving to similar conclusions for the US mortgage lending, Purnanandam (2011) show that banks with high involvement in the originate to distribute model during the pre-crisis period originated excessively poor-quality mortgages. They find that the originating banks did not expend resources in screening their borrowers and that lack of screening incentives coupled with leverage-induced risk-taking behavior significantly contributed to the mortgage crisis. Dell'Ariccia et al. (2010) show that denial rates were relatively lower in areas that experienced faster credit demand growth and that banks in these high-growth areas attached less weight to applicants' loan-to-income ratios. The decline in lending standards was more prevalent especially in areas with higher mortgage securitisation rates. Another study is by Mian and Sufi (2009) which points out to bank moral hazard as one of the main causes of the sub-prime mortgage crisis. They find that prior to the crisis, in the US high latent demand zip codes experienced large relative decreases in denial rates, increases in mortgages originated, and increases in house price appreciation, despite the fact that these zip codes experienced significantly negative relative income and employment growth. These patterns for high latent demand zip codes were driven by a sharp relative increase in the fraction of loans securitised by originators shortly after origination. For Europe, Kara et al. (2011) find that banks that are more active at originating ABS loosened more aggressively their lending standards, by pricing corporate loans cheaper, in the run up to the recent financial crisis.

There is also evidence that securitisation may have impacted on the monetary authorities ability to affect bank lending activity which in turn may have an indirect effect on financial stability and 
regulation. Loutskina (2011) observed this effect in the US and argued that securitisation also makes banks more susceptible to liquidity and funding crisis when the securitisation market is shut down. For Europe, Altunbas et al. (2009) claim that the changing role of credit intermediaries due to securitisation has also modified the effectiveness of the bank lending channel and banks' ability to grant loans. They find that the use of securitisation shelters banks' loan supply from the effects of monetary policy ${ }^{16}$.

Other studies do not find evidence securitisation led to risky lending. For example, Benmelech et al. (2012) investigate whether securitisation was associated with risky lending in the US corporate loan market by examining the ex-post performance of individual loans held by collateralized loan obligations. They examine loan holdings for a large set of collateralised loan obligations (CLOs) and find that adverse selection problems in corporate loan securitisations are less severe (than argued above by other studies). They find that securitised loans are not of less quality than comparable un-securitised loans originated by the same bank. This may provide evidence that, unlike mortgages, securitisation of corporate loans is fundamentally different and does not link to risky lending practices. Shivdasani and Wang (2011) find that banks' underwriting activities in structured credit markets (such as CDOs or CLOs) in the US were associated with greater access to credit for LBOs, cheaper credit prices, and looser covenants. However, these factors did not lead to riskier leveraged buyouts. On the cost of credit part, Nadauld and Weisbach (2012) provide evidence that securitisation caused a reduction in the cost of capital in the US market. They find that spreads on facilities estimated to be more likely to be subsequently securitised have lower spreads than otherwise similar facilities. Albertazzi et al., (2011) examining the 50 Italian banks behaviour for the period between 1996 and 2006, suggest that banks can effectively counter the negative effects of asymmetric information in the securitization market by selling less opaque loans, using signaling devices and building up a reputation for not undermining their own lending standards. Casu et al. (2011), by examining US data, conclude that the net impact of securitisation on the risk-taking behavior of issuing banks and consequently on the soundness of the banking system is ambiguous.

\footnotetext{
${ }^{16}$ In another study looking at the impact of monetary policy as a cause of 2007/08 financial crisis, Maddaloni and Peydró (2011) find that low short-term (monetary policy) rates soften lending standards rather than low long-term interest rates. High securitization activity, weak supervision for bank capital and too low for too long monetary policy rates amplified, especially for mortgages, the softening impact of low monetary policy rates.
} 


\section{Discussion and conclusions}

The rapid expansion of the securitisation market fuelling growth in credit markets is regarded as a primary factor in the 2007/08 global financial crisis by many. Securitisation is not a new and its benefits and costs for banks and financial system has long been discussed extensively in the literature. Since the crisis academic research has intensified putting emphasis on empirical evidence whether securitisation was a culprit of bank behaviour in the build up to the crisis. Hence, in this paper we review the knowledge generated by academic research on the link between securitisation and banking risks.

One noteworthy finding of our review is that, with only one exception (Jiangli et al., 2007), all theoretical studies (Plantin, 2004; DeMarzo, 2005; Greenbaum and Thankor, 1987; Gorton and Pennacchi, 1995; Krahnen and Wilde, 2006; Chiesa, 2008; Parlour and Plantin, 2008; Wagner, 2007; Insterjord, 2005; Shin, 2009; Brunnermeier and Sannikov, 2010), univocally draw attention to the adverse impact of asset securitisation on banks financial soundness and the financial system in general. Theoretical research shows that securitisation may not lead to credit risk diversification. It could not only promote the retention of risky loans and undermine banks' screening and monitoring incentives but also could enhance banks' risk appetite.

In contrast, empirical evidence on the issue does not uniformly support these arguments. On one hand, there is evidence showing that if banks are securitisation active they lend more to risky borrowers (Cebenoyan and Strahan, 2004; Haensel and Krahnen, 2007); Franke and Krahnen, 2005) have less diversified portfolios and hold less capital (Casu et al., 2013), retain riskier loans (Calem and LaCour-Litle, 2003; Martin-Oliver and Saurina, 2007), are aggressive in loan pricing (Kara et al., 2011) and carry high risk in general (Bannier and Hansel, 2006; Michalak and Uhde, 2009; Affinito and Tagliaferri, 2010). On the other hand, there are studies showing that securitisation reduces banks insolvency risk (Jiangli and Pritsker, 2008), increases profitability (Cebenoyan and Strahan, 2004), provides liquidity (Loutskina and Strahan, 2009) and leads to greater supply of loans (Loutskina, 2011; Altunbas et al., 2009; Goderis et al., 2007). Others (Benmelech et al., 2012; Shivdasani and Wang, 2011; Nadauld and Weishbach, 2009; Albertazzi 
et al, 2011; Casu et al., 2011) do not find a link between bank risk taking and securitisation. Taken as a whole, the empirical evidence provided on the link between securitisation and bank risk taking looks to be ambiguous to a certain degree.

On the other hand, a second conclusion that could be drawn from the review is that mortgage lending is an area where there is consistent evidence of bank risk taking through utilising securitisation. Studies, predominantly focusing on US mortgage data (Keys et al., 2010; Purnanandam, 2011; Dell'Ariccia et al., 2010; Mian and Sufi, 2009), find that banks active in mortgage securitisation originated poor-quality mortgages, had lower denial rates, had higher loan default rates and lost their screening and monitoring incentives. In fact, recent court settlement cases in the US between banks and institutional investors and the US government provides anecdotal evidence of banks themselves accepting their misbehaviour.

The inconclusiveness of the literature's findings, no doubt, indicates the need of more research in this area. However, there are certain issues that may lead to these contradictory findings. Firstly, studies examine different segment of the markets, which may not necessarily have comparable features. For example, a majority of studies focusing on the US market utilises mortgage securitisation data and their findings may be incomparable to studies using CLO information as assets underlying these products are fundamentally different. Furthermore, banks' loan decision and process for secured credit, such as mortgages, is substantially distinct from corporate credit that involves relationship lending. More generally, it would be informative to look at how securitisation of loans that are lent through relationship lending (or with soft information) would differ from loans let through credit scoring (or with hard information).

Secondly, as mentioned earlier, there are structural differences between the US and European securitisation markets. Motivations of the banks in engaging securitisation and the impact of securitisation might be heterogeneous across markets depending on differences in accounting standards and regulation. Hence, risks and losses associated with securitisation products have been substantially different across asset types and jurisdictions. For example, in Europe it is estimated that only $0.1 \%$ of residential mortgage backed securities (RMBSs), which accounts for more than half of total European securitisation issuance, defaulted between 2007 and 2013. This 
is in stark contrast to the performance of CDOs of ABSs where the default rate was around $40 \%$ over the same period [European Central Bank (ECB), 2014a] as well as to the performance of RMBSs in the US. Therefore, the research should be extended examining particular types of ABS products and derivatives. There is also scope for further research on how bank risk taking behaviour changes based on jurisdiction

There is also further need to focus on providing empirical evidence for the predictions of the theoretical models, in particular the impact of securitisation on banks monitoring incentives of borrowers whose loans were packed into CLOs. This is essential to answer the question whether the banks picked and sold riskier loans to the CLOs or that the loan quality deteriorated over time as the borrowers' of the loans were not monitored carefully. One way of answering this question is to track and compare the ex-post performance of the securitised versus un-securitised loans. Finally, there is very little research on the demand side factors of securitisation and the causes of increased interest for ABS by investors.

On the regulation front, research has shown that although securitisation provides liquidity benefits for the banks, it also increases the risk taking when lending to new borrowers, which in turn threatens financial stability when there is a downturn in the market. Some argued that regulatory initiatives toward risk-based capital management influenced risk taking behavior by banks. In addition, the existence of deposit insurance together with low bank capital requirements is also linked with retaining risk loans and quality of assets that back ABSs (Greenbaum and Thakor, 1987; and Chiesa, 2008). The research also shows that banks tend to lend too aggressively at the peak of the economic cycle - a finding supporting the debate on procyclicality of bank regulation.

Current developments in regulatory changes aim to address these flaws in the securitisation market. The efforts are concentrated, firstly, on promoting responsible securitisation through measures aiming to align interest between issuer banks and investors. Secondly, regulators focus is on reducing information asymmetries between the counterparties by improving transparency on underlying assets and the ABS structure and to support accurate pricing of credit risk. In this direction, the ECB has introduced loan-level information requirements for ABSs if used as 
collateral in the Eurosystem's credit operations. Recent ECB initiatives also aim to identify qualifying securitisations, which through their simplicity, structural robustness and transparency, would enable investors to model risk with confidence and would provide originators with incentives to behave responsibly (ECB 2014a; ECB 2014b). 


\section{References}

Affinito, M., Tagliaferri, E., 2010. Why do (or did?) banks securitize their loans? Evidence from Italy. Banca D’Italia Temi di discussione (Working papers), Temi di discussione apers), No 741

Albertazzi, U., Eramo, G., Gambacorta, L.,Salleo, C., 2011. Securitisation is Not that Evil after All. Bank of Italy Economic Working Papers 796.

Altunbas, Y., Gambacorta, L., Marques-Ibanez, D., 2009. Securitisation and the Bank Lending Channel. European Economic Review 53, 996-1009.

Ambrose, B.W., LaCour-Little, M., Sanders, A.B., 2005. Does Regulatory Capital Arbitrage, Reputation, or Asymmetric Information Drive Securitisation? Journal of Financial Services Research 28, 113-133.

Association for Financial Markets in Europe, 2007. Securitisation Data Report Q4:2007, available at http://www.afme.eu/Documents/Statistics-and-Reports.aspx

Association for Financial Markets in Europe, 2013. Securitisation Data Report Q4:2013, available at http://www.afme.eu/Documents/Statistics-and-Reports.aspx

Association for Financial Markets in Europe, 2014 . High-quality securitisation for Europe The market at a crossroads, available at http://www.afme.eu/Documents/Statistics-andReports.aspx

Bannier, C.E., Hansel, D.N., 2006. Determinants of banks' engagement in loan securitization. Working paper series: Finance \& Accounting, Johann Wolfgang Goethe-Universität Frankfurt Am Main, No. 171, October 2006

Benmelech, E., Dlugosz, J., Ivashina, V., 2012. Securitisation without Adverse Selection: The Case of CLOs. Journal of Financial Economics 106, 91-113.

Bhattacharya, S., Chiesa, G., 1995. Proprietary Information, Financial Intermediation, and Research Incentives. Journal of Financial Intermediation 4, 328-357.

Brunnermeier, M.K., Sannikov, Y., 2013. A Macroeconomic Model with a Financial Sector. Princeton University, Princeton NJ

Calem, P.S., LaCour-Little, M., 2004. Risk-based Capital Requirements for Mortgage Loans. Journal of Banking \& Finance 28, 647-672.

Calomiris, C.W., Mason, J.R., 2003. Credit Card Securitization And Regulatory Arbitrage. Working Paper No. 03-7, Federal Reserve Bank Of Philadelphia

Casu, B., Clare, A., Sarkisyan, A., Thomas, S., 2011. Does securitization reduce credit risk taking? Empirical evidence from US bank holding companies, The European Journal of Finance, 17:9-10, 769-788

Casu, B., Clare, A., Sarkisyan, A., Thomas, S., 2013. Securitisation and Bank Performance. Journal of Money, Credit and Banking 45, 1617-1658.

Cebenoyan, A.S., Strahan, P.E., 2004. Risk Management, Capital Structure and Lending at Banks. Journal of Banking and Finance 28, 19-43.

Chiesa, G., 2008. Optimal Credit Risk Transfer, Monitored Finance, and Banks. Journal of Financial Intermediation 17, 464-477.

Dell'Ariccia, G., Igan, D., Laeven, L., 2012. Credit Booms and Lending Standards: Evidence from the Subprime Mortgage Market. Journal of Money, Credit and Banking 44, 367384. 
DeMarzo, P.M., 2005. The Pooling and Tranching of Securities: A Model of Informed Intermediation. Review of Financial Studies 18, 1-35.

Diamond, D.W., 1984. Financial Intermediation and Delegated Monitoring. Review of Economic Studies 51, 393-414.

Duffie, D., 2008. Innovations in Credit Risk Transfer: Implications for Financial Stability. Bank of International Settlements, Basle

European Central Bank, 2014a. The Impaired Eu Securitisation Market: Causes, Roadblocks and How To Deal with them. Available at https://www.ecb.europa.eu/pub/pdf/other/ecbboe_impaired_eu_securitisation_marketen.pdf

European Central Bank, 2014b. The case for a better functioning securitisation market in the European Union. European Central Bank Discussion paper. Available at https://www.ecb.europa.eu/pub/pdf/other/ecb-

boe_case_better_functioning_securitisation_marketen.pdf

European Securitisation Forum, 2006. European Securitisation. Available at http://people.stern.nyu.edu/igiddy/ABS/resourceguide.pdf

Franke, G., Krahnen, J.P., 2005. Default Risk Sharing between Banks and Markets: The Contribution of Collateralized Debt Obligations. NBER Working Paper, available at http://www.nber.org/chapters/c9620

Goderis, B., Marsh, I., Vall Castello, J., Wagner, W., 2007. Bank Behaviour with Access to Credit Risk Transfer Markets. Bank of Finland, Helsinki.

Gorton, G.B., Pennacchi, G.G., 1995. Banks and Loan Sales: Marketing Nonmarketable Assets. Journal of Monetary Economics 35, 389-411.

Gorton, G.B., Souleles, N.S., 2004. Special Purpose Vehicles and Securitization. NBER Working Paper, available at http://www.nber.org/chapters/c9619

Greenbaum, S.I., Thakor, A.V., 1987. Bank Funding Modes: Securitisation versus Deposits. Journal of Banking and Finance 11, 379-401.

Greenspan, A., 2005. Risk Transfer and Financial Stability. Federal Reserve Bank of Chicago, Chicago IL.

Haensel, D., Krahnen, J.P., 2007. Does Credit Securitisation Reduce Bank Risk? Evidence from the European CDO Market. Goethe University, Frankfurt am Main.

Holmstrom, B., Tirole, J., 1997. Financial Intermediation, Loanable Funds, and the Real Sector. Quarterly Journal of Economics 112, 663-691.

Instefjord, N., 2005. Risk and Hedging: Do Credit Derivatives Increase Bank Risk? Journal of Banking and Finance 29, 333-345.

Jiangli, W., Pritsker, M., Raupach, P., 2007. Banking and Securitisation. FDIC, Washington DC.

Jiangli, W., Pritsker, M., 2008. The Impacts of Securitization on US Bank Holding Companies. Available at SSRN: http://ssrn.com/abstract=1102284

Kara, A., Ongena, S., Marques-Ibanex, D., 2011, Securitization and Lending Standards: Evidence from the Wholesale Loan Market, European Central Bank Working Paper Series, 38 pp., No 1362.

Keys, B.J., Mukherjee, T.K., Seru, A., Vig, V., 2011. Did Securitisation Lead to Lax Screening: Evidence from Subprime Loans 2001-2006. Quarterly Journal of Economics 125, 307362.

Krahnen, J.P., Wilde, C., 2008. Risk Transfer with CDOs. Goethe University, Frankfurt am Main. 
Loutskina, E., 2011. The Role of Securitisation in Bank Liquidity and Funding Management. Journal of Financial Economics 100, 663-284.

Loutskina, E., Strahan, P.E., 2009. Securitisation and the Declining Impact of Bank Finance on Loan Supply: Evidence from Mortgage Acceptance Rates. Journal of Finance 64, 861889.

Maddaloni, A., Peydró, J.-L., 2011. Bank Risk-taking, Securitisation, Supervision, and Low Interest Rates: Evidence from Euro-area and U.S. Lending Standards. Review of Financial Studies 24, 2121-2165.

Martín-Oliver, A., Saurina, J., 2007. Why do banks securitize assets? In: XV Spanish Finance Forum Conference Proceedings. Spanish Finance Association, Palma de Mallorca

Mian, A., Sufi, A., 2009. The Consequences of Mortgage Credit Expansion: Evidence from the U.S. Mortgage Default Crisis. Quarterly Journal of Economics 124, 1449-1496.

Michalak, T.C., Uhde, A., 2013. Credit Risk Securitisation and Bank Soundness: Evidence from the Microlevel for Europe. Quarterly Review of Economics and Finance 52, 272-285.

Minton, B.A., Sanders, A.B., Strahan P.E., 2004. Securitization by Banks and Finance Companies: Efficient Contracting or Regulatory Arbitrage? Working Paper, Ohio State University.

Nadauld, T.D., Weisbach, M.S., 2012. Did Securitisation Affect the Cost of Corporate Debt? Journal of Financial Economics 105, 332-352.

Parlour, C.A., Plantin, G., 2008. Loan Sales and Relationship Banking. Journal of Finance 63, 1291-1314.

Petersen, M.A., Rajan, R.G., 2002. Does Distance Still Matter? The Information Revolution in Small Business Lending. Journal of Finance 57, 2533-2570.

Plantin, G., 2004. Tranching. Discussion paper, 449. Financial Markets Group, London School of Economics and Political Science, London, UK.

Purnanandam, A., 2011. Originate-to-distribute Model and the Subprime Mortgage Crisis. Review of Financial Studies 24, 1881-1915.

Ramakrishnan, R.T.S., Thakor, A.V., 1984. Information Reliability and a Theory of Financial Intermediation. Review of Economic Studies 51, 415-432.

Shin, H.S., 2009. Securitisation and Financial Stability. Economic Journal 119, 309-332.

Shivdasani, A., Wang, Y., 2011. Did Structured Credit Fuel the LBO Boom? Journal of Finance 66, 1291-1328.

Wagner, W., 2007. The Liquidity of Bank Assets and Banking Stability. Journal of Banking and Finance 31, 121-139.

Watson, R., Carter, J., 2006. Asset Securitisation and Synthetic Structures: Innovations in the European Credit Markets. Euromoney Books, London. 